\title{
Redemptive-historical narrative preaching as a homiletical alternative for preaching on suffering
}

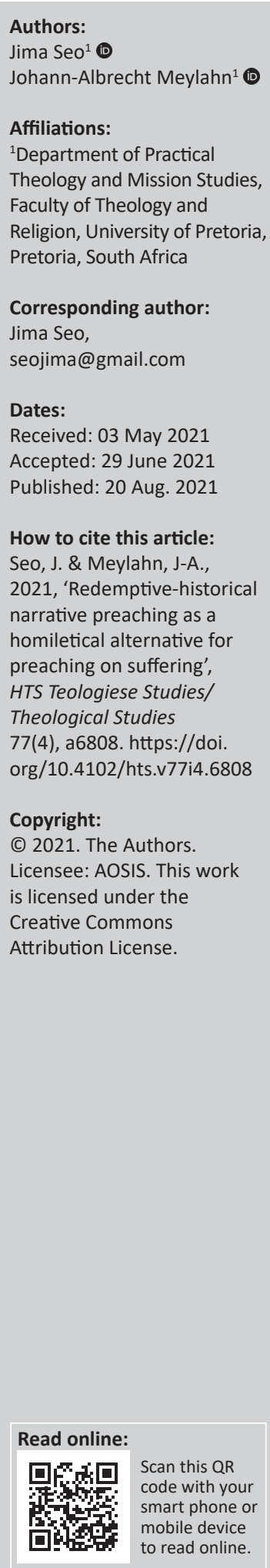

Humans live by experiencing various types of sufferings, directly or indirectly. For this reason, it is evident that one of the topics of great interest in congregations is the question of suffering. This study aims to present redemptive-historical narrative preaching as a homiletical strategy for preaching on suffering. Redemptive-historical narrative preaching can be a homiletical alternative for preaching on suffering because it improves the weaknesses of the traditional homiletic and new homiletic and further develops their strengths. In this study, we will identify the main problems of preaching on suffering in Korean churches. Then, we will discuss redemptive-historical preaching and narrative preaching, which form the foundation of redemptive-historical narrative preaching. Finally, we will propose and explain the redemptive-historical narrative preaching in detail and why it is suitable to respond to contexts of suffering within congregations.

Contribution: Redemptive-historical narrative preaching has greater significance, not only in terms of overcoming the limitations of redemptive-historical preaching and narrative preaching but also in maximising the advantages of both. This research would contribute to the field of homiletics of the Hervormde Teologiese Studies journal.

Keywords: preaching on suffering; traditional homiletic; new homiletic; redemptive-historical preaching; narrative preaching; $\pi \varepsilon \rho \iota \pi \varepsilon ́ \tau \varepsilon ı \alpha$ (reversal); God-centered big idea.

\section{Introduction}

The congregation listening to the Word of God in the sermon wants to know the meaning of their suffering, and how to understand, interpret and deal with it. They ask the preacher to provide a biblical answer to the suffering and thus preachers cannot avoid or omit to preach on suffering. Despite the importance and the necessity of preaching on suffering, it is difficult to find a homiletical study on how to preach on suffering. Therefore, in this study, we would like to present a homiletical alternative for preaching on suffering. This study focuses on the two central tasks of homiletics: interpretation and delivery. Preaching is a hermeneutic action in the sense that it focuses on dealing with understanding the meaning of a given text, and it is a communicative action because it ultimately aims to deliver the meaning through the communication with the audience (Robinson 1999:69). Interpretation and delivery give the sermon its validity and vitality. Firstly, the validity of the sermon can be obtained depending on the interpretation. For example, if a preacher makes an atomic interpretation, the sermon can distort what the text wants to say or be an anthropocentric sermon (Greidanus 2001:6064). Secondly, the vitality of the sermon can be obtained depending on how effectively the preacher delivers. For example, a sermon that clearly reveals the message of the Bible but is not effectively delivered to the audience is likely to end up as a mere statement or commentary (Jeong 2008:24). The interpretation and delivery also cannot be overlooked in preaching on suffering. Depending on what interpretation is taken, the validity of preaching on suffering is secured. Depending on how the interpretation is effectively conveyed, the vitality of preaching on suffering can be secured. For these reasons, in this article, we first analyse the interpretation and delivery of preaching on suffering. Specifically, this study has its focus on Korean Churches. Secondly, we will discuss redemptive-historical preaching and narrative preaching. They provide homiletical insights for interpretation and delivery. Then, the article will finally introduce redemptive-historical narrative preaching as a homiletical alternative for preaching on suffering. 


\section{The problems of preaching on suffering in Korean churches}

In this study, we adopt the Heidelberg method for sermon analysis that Rudolf Bohren and Gerd Debus developed. The advantage of this method is that it has the potential to reveal the preacher's homiletical perspectives. It also identifies problems and contradictions that may appear in the sermon. Also, it reflects on the ideology of preachers and discusses contemporary preaching trends (Cilliers 2006:8-11). The Heidelberg method of sermon analysis consists of basic homiletical questions and linguistic questions. Homiletical questions show the message that God is trying to say in the text. Linguistic questions show the message that the preacher wants to convey. If different thoughts are discovered between the homiletical and linguistic questions, it can be argued that the preacher does not correctly convey what the text intends to communicate. However, instead of directly using the Heidelberg method, we would like to revise it. The advantage of the Heidelberg method is that it can be used efficiently by omitting or combining one or two questions (Park 2012:142-143). Firstly, we replace the linguistic questions with revised linguistic questions as shown in Table 1. Secondly, we replace the homiletical questions with revised homiletical questions as shown in Table 2 .

Through sermon analysis, we identified two main problems with regard to interpretation and delivery. The first problem is eisegesis. Eisegesis is the process of interpreting the text through one's own presuppositions, agendas or biases (Webster 1976:364). Eisegesis is the act of imposing meaning on the text. It is often described in terms of reading 'into' the text rather than 'out of' it. The sermon analysis proves that preachers take one element like joy, praise from the text for atomistic interpretation. Preachers are distorting the text to

TABLE 1: Revised linguistic questions for the sermon analysis.

\begin{tabular}{l}
\hline \multicolumn{2}{c}{ Linguistic questions } \\
\begin{tabular}{ll}
\hline Before the change (six questions) & After the change (four questions) \\
\hline (1) What is the introduction of the sermon? & (1) What is the introduction of the \\
sermon?
\end{tabular} \\
$\begin{array}{ll}\text { (2) What is the conclusion of the sermon? } & \text { (2) What is the conclusion of the } \\
\text { sermon? }\end{array}$ \\
$\begin{array}{ll}\text { (3) What is the form of the sermon? } & \text { (3) What is the form of the sermon? } \\
\text { (4) What conditional sentences are } & \text { (4) What is the hypothesis or argument } \\
\text { included in the sermon? } & \text { for suffering used in this sermon? } \\
\text { (5) Where, and what is a logical } & \\
\text { interruption or irritation to you? } & \\
\text { (6) What is the negation of a preacher? } & -\end{array}$
\end{tabular}

TABLE 2: Revised homiletical questions for the sermon analysis.

\begin{tabular}{ll}
\hline \multicolumn{1}{c}{ Homiletical questions } \\
\hline Before the change & After the change \\
$\begin{array}{ll}\text { (1) Which God is referred to? } & \text { (1) Which God is revealed in the sermon? } \\
\begin{array}{ll}\text { (2) How is the biblical text included in } \\
\text { the sermon? }\end{array} & \begin{array}{l}\text { (2) How does the sermon interpret the text? } \\
\text { How does the sermon interpret the } \\
\text { suffering in the text? }\end{array} \\
\begin{array}{ll}\text { (3) What kind of congregation does the } \\
\text { sermon appeal? }\end{array} & \begin{array}{l}\text { (3) How is the audience described in the } \\
\text { sermon? How does the preacher approach } \\
\text { the congregation who is suffering? }\end{array} \\
\begin{array}{ll}\text { (4) What is the role of the preacher in } \\
\text { the sermon? }\end{array} & \text { (4) What image of the preacher can be } \\
\text { found in the sermon? }\end{array}$ \\
\hline
\end{tabular}

justify their presuppositions, agendas or biases. The second problem is the absence of an effective sermon form for preaching on suffering. Jeong (2009:306) pointed out that the sermon form used for preaching on suffering in most Korean churches is a three-point form. The deductive form focuses on making the audience understand and accept the meaning of suffering. The sermon analysis shows that preachers merely focuses on delivering something about suffering, not taking into account an effective sermon form for preaching on suffering. Even if the interpretation is excellent, the preaching that only conveys interpretation is likely to be an objective lecture on suffering.

\section{Narrative preaching and redemptive-historical preaching}

Before proposing redemptive-historical narrative preaching, we discuss redemptive-historical preaching and narrative preaching that are the foundation of redemptive-historical narrative preaching. Even though these seem to be out of date or a theological cliché to some people today, they still provide us with very useful insights and they are the theories that represent traditional homiletic and new homiletic.

\section{Narrative and plot}

The term 'narrative' has recently been used not only in literature but also in various fields of Christian theology. The definition of narrative varies slightly depending on point of view or emphasis. Narrative can be understood as a literary genre (MacIntyre 1981; Ricœur 1984; Ruf 1994). Narrative has literary elements such as characters, events, background and a plot that reveal the progress of the events or acts. However, narrative goes beyond just providing information or data, it also includes the intention and interpretation of the speaker (Alter 1981:46; Parker 1997:4; Patrick \& Scult 1990:29). Therefore, I define narrative as follows: the narrative is a story that consists of literary elements, including the author's intention or interpretation.

The key to narratives is a plot (Abrams 1997:97). A plot is a literary artifice that has been used since the birth of Greek rhetoric (Ruf 1994:801). Aristotle (1999:133-134) defines a plot (mythos) as 'the composition of the events' in poetics. The plot structure of the tragedy presented by Aristotle consists of a beginning, middle and an end. Aristotle teaches that tragedy should have a detailed plot that begins with $\dot{\alpha} \mu \alpha \rho^{\prime} \alpha$, goes

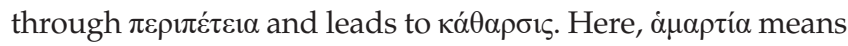
'to miss the mark' or 'to err', $\pi \varepsilon \rho ı \varepsilon \varepsilon \varepsilon \varepsilon 1 \alpha$ means 'a reversal of

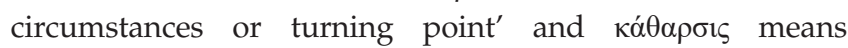
'purification', 'cleansing' or 'clarification' (Park 2013:67).

In preaching, narrative is also an effective means of communication. This is because it allows a preacher to communicate a big idea naturally without directly addressing the audience (Robinson 2014:90). Mathewson (2004:200-201) said that plots serve as devices for keeping the audience in a tense state, strategically delaying a big idea the author wants to convey. 


\section{Narrative preaching and homiletical evaluation of narrative preaching}

The term 'narrative preaching' refers to preaching containing some form of plot (Lowry 1985). Lowry (1980:12) argued that preaching is not a lecture that presents a concept through several points, but 'an event-in-time which follows the logic born of the communication interaction between preacher and congregation'. Lowry suggests the homiletical plot as a key ingredient that stimulates this tension and curiosity. Lowry explains the homiletical plot (Lowry loop) in five steps as follows: (1) Upsetting the equilibrium: The preacher induces tension and ambiguity at the beginning of the sermon by adding something quite opposite of what the audience would expect (Lowry 1980:31). (2) Analysing the discrepancy: 'The purpose for stage two is not simply for a resolution to be reached but also for a readiness for resolution to be developed' (Lowry 1980:45). (3) Disclosing the clue to resolution: In this step, Lowry (1980:48) emphasised the word 'principle of reversal'. This reversal provides surprise and expectation in the audience. (4) Experiencing the gospel: In this step, the audience realises that the 'human fulfilment' mentality they cling to is meaningless, and experience the gospel (Lowry 1980:66). (5) Anticipating the consequences: The audience who experiences the truth of the gospel in preaching will look forward to the positive results that the Gospel will bring.

The biggest contribution of narrative preaching is the emphasis on the role of sermon form, and the importance of biblical narrative. Lowry proves through the homiletical plot that the contents of the sermon could be delivered more effectively. Also, narrative preaching urges preachers to be interested in the narratives that appear in the Bible (Thompson 2001:7). The second contribution of narrative preaching is that it has provided a new theological understanding of the audience. In traditional sermons, the audience is in the passive position of merely listening. In narrative preaching, the audience becomes an active participant in taking a journey with a preacher (Kim 2007:159-161). The third contribution of narrative preaching is making the audience realise the greatness of the Gospel. Narrative preaching does not only make the audience rethink their lives but also helps them to truly understand the gospel (Allen 1998:94).

There are also problems with narrative preaching. The first is that the author's intentions can be distorted. Even if the importance of the audience is emphasised, it is dangerous to pursue meaning beyond the text or to allow the audience to make their own conclusions (Long 2016:125-126).The second problem is that narrative preaching sets the audience's experience as the purpose of the sermon. It distorts the nature of the sermon to think that the purpose of the sermon is achieved only when the experience occurs in the sermon (Long 2016:48). The third problem is that narrative preaching insists on an open ending. Attempting to leave the conclusion to the audience may stand in contrast to the text or the author's intention because the diversity of the audience and the tendency to self-centered interpretation (Thompson
2001:13-14). The fourth problem is that the narrative preaching focuses on personal experience, so it is vulnerable in establishing a faith community. According to Campbell (1997:144), narrative preaching has so far provided no resources to think carefully about establishing the people of God as a community. Narrative preaching whose main purpose is to produce personal experience is an example of the experiential-expressive model, which falls in the framework of modern liberalism (Campbell 1997:121-122). The fifth problem is that the Gospel presented by the narrative preaching is replaced by the subjective gospel. Campbell (1997:142) pointed out that the emphasis on experience eventually degrades the Gospel to the 'theological relationalism' that makes God too dependent on immediate human experience.

\section{Redemptive history and redemptive-historical interpretation}

Redemptive history is a debated term that is also called Salvation history, sacred/holy history, Heilsgeschichte in German (Soulen 1981:82) or biblical history of Israel (Waltke \& Yu 2007:53). In this study, we would like to limit the use of the term 'redemptive history' to the terms used in relation to a particular view of biblical theology. There are four premises in redemptive history. Firstly, redemptive history is God's sovereign history (Greidanus 2001:122). Secondly, redemptive history is a single narrative centred on Jesus Christ (Clowney 2002:74-77). Thirdly, redemptive history is progressive (Seo 2016:5). Fourthly, redemptive history is unity (Cho 2012:10). Based on these four premises, this study seeks to define redemptive history as follows: redemptive history is the process of all historical acts in which God, who is sovereign, progressively and organically performs redemption through Jesus Christ.

It is required for preachers to interpret and preach the text from a redemptive-historical approach. This is because God's redemption is the purpose of the Bible, showing the audience that God is still active in their lives today (Vos 2003:5-6). The interpretation of the text cannot be solved simply by familiarisation with some methods of biblical interpretation. Before interpretation of the text, preachers need to keep in mind that the events recorded in the Bible are not mere events, but events of redemptive history. How can the preacher make a redemptive-historical interpretation? The Bible is interlinked with the theological theme of redemption, the historical events that embody this theological theme through history and the literary form as a communication strategy to convey the theological theme (Greidanus 1988:49-51). For this reason, three interpretation methods are needed: grammatical-historical interpretation, organic interpretation and synthetic interpretation. Grammaticalhistorical interpretation is the interpretation that studies grammatical elements such as words, sentences, expressions and genres and the time and circumstances in which the author wrote especially the author's background and circumstance (Chapell 2005:77). Organic interpretation is to 
interpret the text in relation to the entire redemptive history. Organic interpretation handles a text as part of an organic body, viewing the text in relation to the whole scheme, namely the unity of redemptive history (Greidanus 2001:135-136). Synthetic interpretation is to interpret the text within its uniqueness (Greidanus 2001:133-134). Synthetic interpretation seeks to do justice to the uniqueness of each historical text by considering a specific synthesis at that particular place in history of all elements within the text (Greidanus 2001:138).

\section{Redemptive-historical preaching and homiletical evaluation of redemptive-historical preaching}

Dutch Calvinists in the late 1930s started using the term 'redemptive-historical preaching'. Between World War I and II there was a 'new direction' taking place in Gereformeerde Kerken (Reformed Churches) in Holland (Greidanus 2001:22-24). The 'new direction' was an attempt to establish the Calvinistic philosophy, which includes issues in dogma and homiletics. The 'new direction', motivated by its counterparts in philosophy and theology, sought the answer through a new method of preaching: redemptive-historical preaching. Firstly, the emphasis on redemptive-historical preaching of the 'new direction' is a reaction to the historical approach of dialectical theology (Greidanus 2001:29-32). Secondly, redemptive-historical preaching is a reaction to the subjectivism of reformed Churches in Holland (Greidanus 2001:33-35). Thirdly, redemptive-historical preaching is a reaction to exemplary sermons centred on illustrative interpretation, fragmentary interpretation and atomistic interpretation.

Redemptive-historical preaching is to preach the recorded redemptive history of God found in the text (Jeong 2006:498). The goal of redemptive-historical preaching is to contemporize redemption recorded in the text in people of 'here and now' through preaching (Lee 2013:132). This is important because redemptive history does not stop in the text, but continues in our life. Therefore, redemptivehistorical preaching is to witness the redemptive work of God through the text and to proclaim God who is still caring for his people in the same way and with the same ability as in the text (Lee 2012:709).

It can be said that redemptive-historical preaching made an important contribution to homiletics in that it secured biblicaltheological legitimacy. Redemptive-historical preaching contributed to revealing the location of the particular text in redemptive history based on the unity of the Bible and the organic continuity of the revelation through finding theological meaning from the text (Jeong 2003:43). Despite these contributions, however, redemptive-historical preaching has its problems. The first problem is the hasty application of redemptive-historical approach in interpretation. When a preacher ignores grammatical-historical interpretation and hastily draws up a redemptive-historical approach to the text, there is the possibility that the text will not be interpreted correctly (Cho 2012:30). The second problem is the negative view towards the application. Some proponents of redemptive-historical preaching regard redemptivehistorical interpretation as redemptive-historical preaching (Jeong 2006:506). Simply declaring redemptive history cannot be the application of the text (Krabbendam 1993:185). The third problem is obsession with mention of Christ. Some proponents of redemptive-historical preaching believe that whatever text a preacher chooses should always refer to Christ or his ministry (Jeong 2006:507). These attempts eventually lead to an allegorical interpretation. The principle of Christocentricity in redemptive-historical preaching does not mean that a preacher must refer to Jesus Christ in the sermon. The term 'Christocentric' means that the text should be interpreted organically from the perspective of redemption that focuses on Christ (Greidanus 1988:119).

\section{Redemptive-historical narrative preaching}

We propose redemptive-historical narrative preaching as an alternative to preaching on suffering. Redemptive-historical narrative preaching that this study proposes is to interpret the text from the redemptive-historical perspective and convey the God-centred big idea of the text through the special plot. Redemptive-historical narrative preaching supports the theological position of 'Textus Rex', which means the text is king. Redemptive-historical narrative preaching is based on the text and extracts the big idea from the text. Redemptive-historical narrative preaching is also an effort to take advantage of narrative preaching, which focuses on movement and continuity. Koreans are not used to express their sufferings effectively. The reason is that Korea is a country that follows the culture of Confucianism. Koreans who have learned and lived in Confucianism culture think it is shameful to express suffering. For Koreans, suffering is a burden to bear on themselves. They believe that expressing or sharing sufferings with others is damaging to them. For example, Korea has the highest suicide rate amongst Organization for Economic Cooperation and Development (OECD) countries. This atmosphere shows that Koreans are not used to express their suffering. These characteristics of Koreans are often found in preachers of Korean churches. Korean preachers are used to providing the theological meaning of suffering and biblical interpretation of suffering. But, as pastors, they are not good at empathising and comforting the audience's sufferings. For this reason, it is necessary for preachers to use a particular form to engage the audience in the sermon and we suggested narrative preaching as an effective form. The plot of narrative preaching is effective because it gives the audience the experience of discovering God in preaching, and it encourages audience participation.

\section{The necessity of redemptive- historical narrative preaching}

This study discusses the necessity of redemptive-historical narrative preaching from two perspectives. Firstly, it is 
necessary for the integration of God-centredness and audience-centredness. Wilson (1999:39-44) insisted that a preacher must find God in the text and attain 'God-statement'. Redemptive-historical narrative preaching obtains the big idea, which includes 'God-statement' through redemptivehistorical interpretation. For this reason, this big idea is called the God-centred big idea. The God-centred big idea shows that God is still working amongst the suffering of his people. The God-centred big idea secures audience-centredness through an effective plot. The plot of redemptive-historical narrative preaching has a rhetorical strategic structure (Lee 2017:94). Secondly, redemptive-historical narrative preaching is necessary for the integration of text-centricity and text applicability. Text-centricity refers to the faithfulness of whether the message of the sermon is based on the text, and text's applicability refers to the possibility that the message of 'then and there' can be applied to the lives of the audience 'here and now' (Brown 2003:390; Jeong 2003:9-13). Robinson (2014:3-4) pointed out that modern sermons have lost their vitality because the preacher is tempted to deliver a message other than the Bible's message. Therefore, an interpretation concentrating on the text is required to maintain text-centricity. Redemptive-historical interpretation asks what God is doing in the text and can secure the theological ground from the text. In addition, redemptivehistorical narrative preaching has text applicability. The reason is that redemptive history has a subjective dimension (Vos 2003:6). The text contains text's applicability because God's redemption revealed in the text can still be applied and repeated subjectively in a contemporary audience's life.

\section{Preparation of redemptive-historical narrative preaching}

On the basis of Craddock's argument (2010:84), we divide sermon preparation into two processes. The first process is the interpretation of the text. This process is to study the text, the original source of the sermon. The second process is the configuration of the plot. This process is to give movement and continuity to the God-centred big idea.

The interpretation of the text consists of three main steps: observation, exegesis and finding a God-centred big idea. Firstly, observation is reading and grasping the text. Chapell (2005:107) advised, the text should be carefully observed to ensure the content is understood, even though the meaning may not be. Secondly, exegesis is to find what the text means (Osborne 2010:22). This study suggests redemptive-historical interpretation as a hermeneutical key to interpretation. Redemptive-historical interpretation presupposes grammatical-historical interpretation and also includes organic and synthetic interpretation. Thirdly, Godcentred big idea is the big idea of the text in which God is the subject. Robinson (2014:16-17) defined the big idea as a single dominant idea that can summarise the text. The big idea has two components (Robinson 2014:20-26). The first is 'subject'. The subject of the big idea is an accurate answer to what the author is talking about in the text. The second is 'complement'.
The complement of the big idea is the answer to what the author says about the subject in the text. In redemptivehistorical narrative preaching, the main agent of the big idea becomes God. Greidanus (1988:113-114) and Wilson (1999:39-40) argued that the big idea of the sermon should be theocentric, not anthropocentric. Based on their arguments, this study asserts that the big idea of redemptive-historical narrative preaching should be a theocentric big idea called a 'God-centred big idea'. God-centred big ideas consist of a God-centred subject and a God-centred component. A Godcentred subject has to do with what the text says about God. God-centred component is the answer to what it says about the God-centred subject.

Von Balthasar (1990) attempted to resolve the theological conflict between God's absolute sovereignty and human freedom through drama theory. Vanhoozer (2005) is influenced by Balthasar and suggests Theo-dramatic theology. Vanhoozer focuses on the Bible, which is 'the script' and explains God (the author) develops his theories regarding doctrine, church and the actor. These theories attempt to include the significant Christian doctrine of 'soteriology' through drama. Balthasar and Vanhoozer regard God's drama of redemption as Theo-drama that records God's dispensation and providence (Park 2012:167). Theo-drama is a narrative of the great reversal (Steinmann 2006:95; Verhey 1984:94). As shown in Figure 1, Adam's sin has broken humanity's relationship with God, and there is no possibility of restoring this relationship (conflict). Human beings gradually drifted away from God, and the law indicates the impossibility of humanity's situation

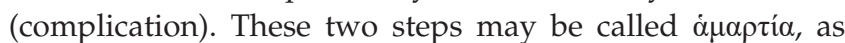
explained by Aristotle. But Jesus Christ, the only begotten Son of God, came to this world to bear the sin of mankind. Jesus Christ broke the power of death, and rose 3 days after his crucifixion, sending the Holy Spirit to his people so that they can be exalted (reversal). This was an amazing reversal that turned impossibility to possibility. This reversal may be

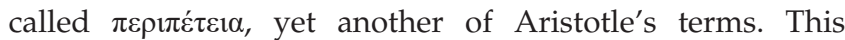
reversal made sinners new creatures. In addition, Jesus Christ will make a second coming, and then the world will be fully restored (resolution). However, Theo-drama requires believers to live as the people of God who have been saved.

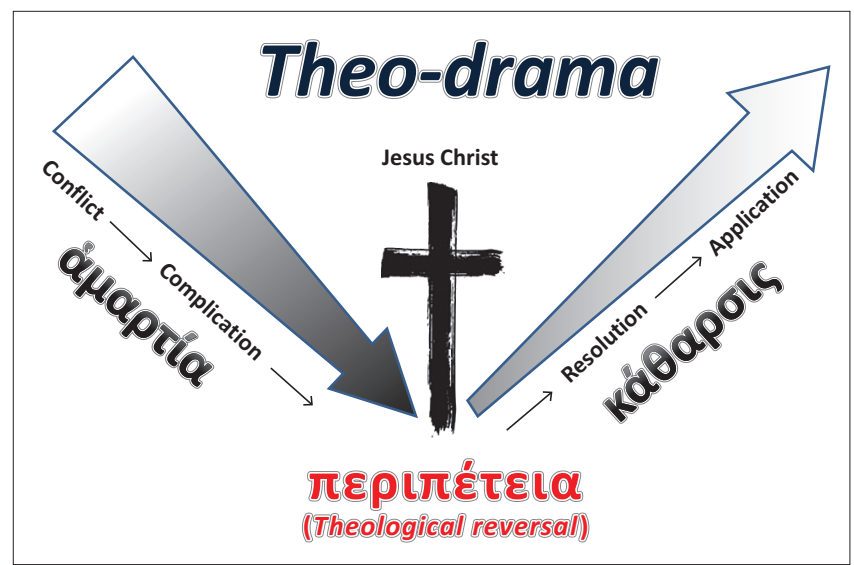

FIGURE 1: The plot of redemptive-history narrative preaching. 
Therefore, as the final step in Theo-drama is the application. For this reason, reversal and application may be called

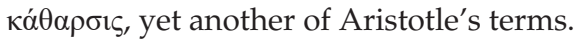

When the God-centred big idea originates from a redemptivehistorical approach, the plot of redemptive-historical narrative preaching is a modification of Lowry's homiletic plot in light of the character of Theo-drama and the nature of preaching. The plot of redemptive-historical narrative preaching is as follows: conflict, complication, theological reversal, resolution and application. What makes the plot proposed in this study different from Lowry's homiletical plot is that the reversal has changed into a theological reversal and the application has been added.

\section{Conflict}

This step is to identify and present conflict or problems that appear in the text. It is important to note that conflict should be based on the God-centred big idea in the text when presenting conflict in the beginning. This attempt is intended to overcome the limitations of conflict presented by narrative preaching. Lowry's narrative preaching focuses on presenting conflict or problems simply to arouse or stimulate the audience's interest (Ryu 2005:200-201). The Bible shows the 'total depravity' of human beings and that all the problems stem from this (Chapell 2005:105-106). When presenting conflict based on this theological principle, the audience naturally expects God's grace.

\section{Complication}

If preachers capture the interest of the audience through conflict, they need to elaborate on the aspects that cause conflict. Lowry (1997:66-70) argued that the purpose of complication is to deepen our understanding of conflict. Conflict can be complicated through various methods. Firstly, a preacher can use an example or illustration associated with today's audience. Secondly, a preacher can refer to a story or example from the Bible. Thirdly, conflict can be complicated by combining the methods discussed earlier.

\section{Theological reversal}

The biblical texts show us the work and providence of God, rather than focusing on conflicts and problems. Therefore, if the sermon is faithful to the text, there should be a recovery from conflict, solving of problems and a theological movement to grace (Wilson 1999:156-157). This theological movement can be called reversal in the sermon. If conflict has been presented and complicated, it is important to show how God can solve the conflict. For this reason, this study refers to the term 'theological reversal'. Theological reversal is helpful in the following ways. Firstly, when focusing on God's action, preaching can be distanced from the humancentred preaching that emphasises human behaviour and faith. Secondly, as the text provides the answer to the conflict, the experience of the audience can avoid the danger of being subjective.

\section{Resolution}

The solution proposed by this study does not imply that a preacher is capable of providing alternatives or answers to solve suffering. The solution this study proposes is to show the audience a new possibility, which comes from God. If the theological reversal is to show what God is doing in our lives, whilst the solution is to declare what God will do and what change will be in our life. For these reasons, resolution is similar to 'Yeah!', the last step of the homiletical plot in narrative preaching. The solution provides details of the possible outcomes that we can expect (Lowry 1980:72-73).

\section{Application}

This study presents the application as the final step of the plot. There are two reasons for the application. Firstly, because the sermon cannot merely be an objective explanation of God's salvation that has occurred in the past, it should proclaim the salvation of redemptive history and suggest an application of the subjective dimension of redemptive history that can be repeated in today's congregation (Lee 2012:34). Chapell (2005:54) claimed that 'preaching without application may serve the mind, but preaching with application results in service to Christ'. The sermon does not merely provide information to the audience but also encourages them to be like Christ (Sunukjian 2007:12).

\section{Conclusion}

With the advent of the new homiletic, the homiletic has become more interested in the audience than ever before, and the field of research has expanded widely. The challenge of the new homiletic cannot be ignored and should be highly appreciated. However, new attempts to overcome the crisis of preaching have resulted in a greater crisis than before because of the absence of theology and an obsession with delivery. The authority of the Bible and its message have been overlooked in the new homiletic.

How do we overcome this new crisis? This study was initiated by this concern, and we proposes redemptivehistorical narrative preaching that harmonised with the narrative preaching of the new homiletic, and the redemptivehistorical preaching of the traditional homiletic. Firstly, redemptive-historical narrative preaching is an alternative that can overcome the limitations of the new homiletic, which ignores the authority of the Bible and focuses on delivery. If the merits of the new homiletic, which focus on the audience, are combined with the advantages of redemptive-historical interpretation, which focuses on God's redemptive history, preaching can be 'theology-based' and 'audience-directed'. Secondly, redemptive-historical narrative preaching has greater significance not only in terms of overcoming the limitations of redemptive-historical preaching and narrative preaching but also in maximising the advantages of both. Redemptive-historical narrative preaching will be a breakthrough, contributing to the revival of preaching by countering the weaknesses of both the traditional and new homiletics and exploiting their advantages. Thirdly, 
redemptive-historical narrative preaching can lead to the maturity of God's people by not only engaging the audience in the sermon but also emphasising the appropriate application to their situation. In this study, we emphasise the importance of application as a response to God's salvation, which can lead to the maturity of the faith community if applied correctly.

Redemptive-historical narrative preaching is not the only resolution for preaching on suffering. Redemptive-historical narrative preaching is just one of the many alternatives to preaching on suffering. There is no complete homiletical form or method in this world. There is a need for continuous research into redemptive-historical narrative preaching. By trying and applying redemptive-historical narrative preaching in our preaching ministry, we can continue to develop the concept. Through such continuous research, we hope that redemptivehistorical narrative preaching will be a homiletical alternative for the various fields of homiletics, such as the doctrinal sermon, the ethical sermon and the expository sermon.

\section{Acknowledgements Competing interests}

The authors declare that they have no financial or personal relationships that may have inappropriately influenced them in writing this article.

\section{Authors' contributions}

J.S. wrote the article under the supervision of J.A.M.

\section{Ethical considerations}

This article followed all ethical standards for research without direct contact with human or animal subjects.

\section{Funding information}

This research received no specific grant from any funding agency in the public, commercial or not-for-profit sectors.

\section{Data availability}

Data sharing is not applicable to this article as no new data were created or analysed in this study.

\section{Disclaimer}

The views and opinions expressed in this article are those of the authors and do not necessarily reflect the official policy or position of any affiliated agency of the authors.

\section{References}

Abrams, M.H., 1997, Literary terms dictionary, Yelim, Seoul. Allen, R.J., 1998, Patterns of preaching: A sermon sampler, Chalice Press, St. Louis, MO. Alter, R., 1981, The Art of biblical narrative, Basic Books, New York, NY.

Aristotle, 1999, Poetics, Samsung Publishing Company, Seoul.

Brown, D.M., 2003, Transformational preaching: Theory and practice, Virtualbookworm. com Pub. Co, College Station, TX.
Campbell, C.L., 1997, Preaching Jesus: The new directions for homiletics in Hans Frei's Postliberal Theology, W.B. Eerdmans Pub, Grand Rapids, MI.

Chapell, B., 2005, Christ-centred preaching: Redeeming the expository sermon, Baker Academic, Grand Rapids, MI.

Cho, S., 2012, 'A study on legitimacy of application \& orientation towards faith community in redemptive historical preaching', ThD thesis, Hapdong Theological Seminary, Suwon.

Cilliers, J., 2006, God for us: An analysis and assessment of Dutch reformed preaching during the apartheid years, Sun Press, Stellenbosch.

Clowney, E.P., 2002, Preaching and biblical theology, P\&R Publishing, Phillipsburg, NJ. Craddock, F.B., 2010, Preaching, 25th anniversary edn., Abingdon Press, Nashville, TN.

Greidanus, S., 1988, The modern preacher and the ancient text: Interpreting and preaching biblical literature, W.B. Eerdmans Pub, Grand Rapids, MI.

Greidanus, S., 2001, Sola scriptura: Problems and principles in preaching historical texts, Wipf and Stock, Eugene, OR.

Jeong, C., 2003, Communicative preaching, Hapdong Theological Seminary Publisher, Suwon.

Jeong, C., 2006, 'The legitimacy and the limitations of Christologic preaching', Hapshin Theological Journal 24, 497-516.

Jeong, C., 2008, 'Redemptive-historical preaching and biographical preaching', Hermeneia Today 42, 22-37.

Jeong, C., 2009, 'Effective delivery of the sermon and diversification of sermons forms', Hapshin Theological Journal 27, 291-321.

Kim, C., 2007, 'Postmodernism and preaching', The Gospel and Praxis 13, 149-174.

Krabbendam, H., 1993, 'Bible interpretation in redemptive-historical tradition', The Word 11, 182-193.

Lee, S., 2012, 'Redemptive- historical preaching for sanctification', Hapshin Theological Journal 30(2), 697-720.

Lee, S., 2013, 'Preaching ministry based on redemptive-historical perspective', Hapshin Theological Journal 31, 127-160.

Lee, S., 2017, 'A study on the preaching ministry that embodies redemptive-historical narrative', The Gospel and Praxis 43, 79-112.

Long, T.G., 2016, The witness of preaching, 3rd edn., Westminster John Knox Press, Louisville, KY.

Lowry, E.L., 1980, The homiletical plot: The sermon as narrative art form, John Knox Press, Atlanta, GA

Lowry, E.L., 1985, Doing time in the pulpit: The relationship between narrative and preaching, Abingdon Press, Nashville, TN.

Lowry, E.L., 1997, The sermon: Dancing the edge of mystery, Abingdon Press, Nashville, TN.

MacIntyre, A.C., 1981, After virtue: A study in moral theory, University of Notre Dame Press, Notre Dame, IN.

Mathewson, S.D., 2004, The art of preaching Old Testament narrative, Christian Literature Crusade, Seoul.

Osborne, G.R., 2010, The hermeneutical spiral: A comprehensive introduction to biblical interpretation, 2nd edn., IVP Academic, Downers Grove, IL.

Park, J., 2013, The secret of storytelling: The poetics of Aristotle, Humanities Library, Seoul.

Park, S., 2012, 'Sermon analysis: Lee Sang-gun's preaching on apostles' creed', Korea Reformed Theology Society 36, 132-177.

Parker, S.B., 1997, Stories in scripture and inscriptions: Comparative studies on narratives in Northwest Semitic inscriptions and the Hebrew Bible, Oxford University Press, New York, NY.

Patrick, D. \& Scult, A.M., 1990, Rhetoric and biblical interpretation, The Almond Press, Sheffield.

Ricœur, P., 1984, Time and narrative, University of Chicago Press, Chicago, IL.

Robinson, H.W., 1999, 'Homiletics and hermeneutics', in S.M. Gibson (ed.), Making a difference in preaching, pp. 69-84, Baker Academic, Grand Rapids, MI.

Robinson, H.W., 2014, Biblical preaching: The development and delivery of expository messages, 3rd edn., Baker Academic, Grand Rapids, MI.

Ruf, F.J., 1994, 'The consequences of genre: Narrative, lyric, and dramatic intelligibility', Journal of the American Academy of Religion 62(3), 799-818. https://doi. org/10.1093/jaarel/LXII.3.799

Ryu, E., 2005, 'The New Homiletic: A reformed perspective on a current trend in homiletics', Presbyterian Theological Quarterly 72, 183-207.

Seo, J., 2016, Study on a typological interpretation for redemptive historical preaching, ThM thesis, Hapdong Theological Seminary, Suwon.

Soulen, R.N., 1981, Handbook of biblical criticism, J. Knox Press, Atlanta, GA.

Steinmann, A., 2006, Called to be God's people: An Introduction to the Old Testament, Wipf \& Stock, Eugene, OR.

Sunukjian, D.R., 2007, Invitation to biblical preaching: Proclaiming truth with clarity and relevance, Kregel Publications, Grand Rapids, MI.

Thompson, J.W., 2001, Preaching like Paul: Homiletical wisdom for today, Westminster John Knox Press, Louisville, KY.

Vanhoozer, K.J., 2005, The drama of doctrine: A canonical-linguistic approach to Christian Theology, Westminster John Knox Press, Louisville, KY 
Verhey, A., 1984, The great reversal: Ethics and the New Testament, W.B. Eerdmans, Grand Rapids, MI.

Von Balthasar, H.U., 1990, Theo-drama: Theological dramatic theory. Volume II: The Dramatis Personae: Man in God, Ignatius Press, transl. G. Harrison, San Francisco, CA.

Vos, G., 2003, Biblical theology: Old and New Testaments, Wipf and Stock Publishers, Eugene, OR.
Waltke, B.K. \& Yu, C., 2007, An Old Testament Theology, Zondervan, Grand Rapids, MI.

Webster, N., 1976, Webster's New Collegiate Dictionary, G. \& C. Merriam Co, Springfield, MA.

Wilson, P.S., 1999, The four pages of the sermon: A guide to biblical preaching, Abingdon Press, Nashville, TN. 